\title{
Prevalence of traumatic injuries among female workers in garment industry in Dickwella Divisional Secretariat area
}

\author{
Sewwandi H R A ${ }^{1}$, Fonseka N H D P ${ }^{1}$, De Silva P V²
}

\begin{abstract}
Introduction: Work related injuries are a major public health problem in Sri Lanka today. Garment industry is the major foreign exchange earner in Sri Lanka and work related traumatic injuries are more common among workers of garment industry, the majority of which are women.
\end{abstract}

Objectives: This study was conducted to identify the prevalence and associated factors of traumatic injuries among female workers in garment industry.

Methods: A cross-sectional study was conducted among female garment workers working in two garment factories in Dickwella Divisional Secretariat area. Three hundred and twelve workers were randomly selected according to the proportion of total workers in each factory. Data was collected by a self-administered questionnaire. All data was analyzed by using Statistical Package of Social Sciences.

Results: The population consisted of 312 female workers. The mean age range was 26-35 years. Most of the participants $(63.8 \%)$ had educated up to G.C.E. Ordinary Level. One hundred and seventy four (55.8\%) were sewing machine operators. Of the participants 73.1\% worked 8-9 hours per day and $53.5 \%$ worked 6-10 hours per week as over time. Prevalence of traumatic injuries was $35.3 \%$ among workers during the previous 12 months. Rushing at work (46.4\%) was the most common cause followed by carelessness (25.5\%). Puncture injuries (48.2\%) were the commonest type of injuries while contusions and abrasion (19.1\%) were the second commonest type and fingers (57.8\%) were the commonest injured body part. Large majority (91.3\%) of participants were satisfied about the safety of the working environment.

Conclusions There was a high prevalence of traumatic injuries among female workers in garment industry

${ }^{1}$ Final year student, Nursing Degree Programme, Faculty of Medicine, University of Ruhuna

${ }^{1}$ Lecturer, Nursing Degree Programme, Faculty of Medicine, University of Ruhuna

${ }^{2}$ Senior Lecturer, Department of Community Medicine, Faculty of Medicine, University of Ruhuna in Dickwella Divisional Secretariat area. Although the garment factories have a good working environment according to the workers, worker related causes such as rushing at work and carelessness were the major reasons for these injuries.

\section{Introduction}

The garment industry is the largest Sri Lankan gross export earner since 1986 and the major mode of foreign exchange earner since 1992 (1). The export oriented clothing production began in 1970s and expanded rapidly later (2). In late 1970s, Free Trade Zones were established and initially they were established close to the Colombo. But later they were established in other rural areas. After the garment industry has become the largest contributor of export, it surpasses traditional exports such as tea, coconut and rubber.

This industry provides over 300,000 to 600,000 employment opportunities for a majority of women (3). A research performed among 2304 female workers in Export Processing Zones in Sri Lanka revealed that $81.5 \%$ of female workers worked in garment factories (4). Although both men and women workers experience occupational hazards, women are more prone to occupational hazards than men (5).

Work related injuries are concern as a major public health problem today. Traumatic injuries are physical injuries of sudden onset and severity which require immediate medical attention (6).Work place injuries range from minor physical injuries to more serious injuries (7). A study done in New Delhi, India found that major and minor accidents are common in the garment industry (8). Minor accidents include falls, cutting and bruising, fingers getting trapped into machines and injuries due to splash of chemicals.

The most usual organs involved in occupational traumatic injuries are the spine, hands, head, lungs, skin, skeleton and the eyes. There are some common causes of occupational traumatic injuries including,

Manual handling of heavy loads Misuse of equipment

Inadequate training

Poor ergonomics

Failure of equipment

Clothing or long hair that become tangled in machinery. 
There are some general hazards in a work environment including,

\section{Electricity}

Flammable gases

Height

Sharp moving machinery (9).

According an expert opinion expressed in a newspaper there is a rising numbers of workplace accidents in Sri Lanka and women working in garment factories were prime victims. It further states that most often female workers working near Juki machines do not wear necessary head-covers and their hair gets entangled in the machines, and resulting in skin being torn as well. This is partly due to removal of the machinery parts installed to protect operators from injury in many workplaces (10).

According to International Labour Organization, Sri Lanka records around 4000 workplace accidents a year and the most of the accidents occur in the construction and garment industry (10).

\section{Materials and methods}

A cross-sectional study was conducted among female garment workers working in two garment factories in Dickwella Divisional Secretariat area. Three hundred and twelve workers were randomly selected according to the proportion of total workers in each factory. Participants were selected from sewing machine operators, quality control assistants, ironers, packers, cutters, helpers, and supervisors. A self-developed, pre tested, self-administered questionnaire including socio - demographic data, occupational data and details regarding traumatic injuries and associated factors was used. In socio - demographic data section there was questions regarding age, ethnicity, religion, marital status and educational level. In occupational history section there was questions regarding the nature of the job, duration, and over time work. In traumatic injuries and associated factors section there was questions regarding the type of injury, hospitalization and the associated causes. The selected participants were given the questionnaire and approximate time was given to complete it. All data was analyzed by using descriptive statistics. Data was presented by percentages. Results were displayed on each variable by appropriate diagrams such as pie charts and bar charts, using Statistical Package of Social Science (SPSS) version 20.0 as data analysis tool. Pearson's chi square test was used to assess the association between categorical variables. Statistical significance was set at $p<0.05$. Ethical clearance was obtained from the ethical committee of the Faculty of Medicine, University of Ruhuna. The Human Resource manager of the two garment factories were informed through the Dean, Faculty of Medicine prior to the research to obtain permission. Informed written consent was obtained prior to the study from the all study participants after giving a clear idea about the study.

\section{Results}

The study sample consists 312 female workers from two garment factories in Dickwella Divisional Secretariat area. The mean age rage was $26-35$ years. Majority of them (34.6\%) belonged to the age group 16-25 while nearly all of the participants were (99.68\%) Sinhala and Buddhists. 183 (58.7\%) of them were married and 158 (83.2\%) of them had children. Most of the participants had studied up to G.C.E. O/L (63.8\%). There were only 79 participants who had studied up to G.C.E. A/L or more.

Table 1. Demographic Profile

\begin{tabular}{|c|c|c|c|}
\hline Characteristics & Categories & Frequency & Percentage \\
\hline \multirow[t]{5}{*}{ Age } & $16-25$ years & 108 & $34.6 \%$ \\
\hline & 26-35years & 74 & $23.3 \%$ \\
\hline & 36-45years & 70 & $22.4 \%$ \\
\hline & 46-55years & 57 & $18.3 \%$ \\
\hline & $>$ 56yeras & 3 & $0.96 \%$ \\
\hline \multirow[t]{2}{*}{ Ethnicity } & Sinhala & 311 & $99.68 \%$ \\
\hline & Muslim & 1 & $0.32 \%$ \\
\hline \multirow[t]{2}{*}{ Religion } & Buddhist & 311 & $99.68 \%$ \\
\hline & Islam & 1 & $0.32 \%$ \\
\hline \multirow[t]{5}{*}{ Marital status } & Married & 183 & $58.7 \%$ \\
\hline & Unmarried & 121 & $38.8 \%$ \\
\hline & Separated & 2 & $0.6 \%$ \\
\hline & Divorced & 2 & $0.6 \%$ \\
\hline & Widowed & 4 & 1.3 \\
\hline \multirow[t]{6}{*}{$\begin{array}{l}\text { Educational } \\
\text { level }\end{array}$} & $\begin{array}{l}\text { No } \\
\text { schooling }\end{array}$ & 2 & $0.6 \%$ \\
\hline & Grade 1-5 & 6 & $1.9 \%$ \\
\hline & Grade 6-9 & 26 & $8.3 \%$ \\
\hline & $\begin{array}{l}\text { Up to G.C.E. } \\
\text { O/L }\end{array}$ & 199 & $63.8 \%$ \\
\hline & $\begin{array}{l}\text { Up to G.C.E. } \\
A / L\end{array}$ & 77 & $24.7 \%$ \\
\hline & $\begin{array}{l}\text { Up to } \\
\text { university }\end{array}$ & 2 & $0.6 \%$ \\
\hline
\end{tabular}

December 2016 Journal Of The Ruhunu Clinical Society 
Table 2. Occupational profile

\begin{tabular}{|c|c|c|c|}
\hline Characteristics & Categories & Frequency & Percentage \\
\hline \multirow[t]{8}{*}{$\begin{array}{l}\text { Nature of the } \\
\text { job }\end{array}$} & $\begin{array}{l}\text { Sewing machine } \\
\text { operators }\end{array}$ & 174 & $55.8 \%$ \\
\hline & $\begin{array}{l}\text { Quality control } \\
\text { assistants }\end{array}$ & 15 & $4.8 \%$ \\
\hline & Ironer & 7 & $2.2 \%$ \\
\hline & Packer & 8 & $2.6 \%$ \\
\hline & Cutter & 24 & $7.7 \%$ \\
\hline & Helper & 45 & $14.4 \%$ \\
\hline & Supervisor & 18 & $5.8 \%$ \\
\hline & Other & 21 & $6.7 \%$ \\
\hline \multirow[t]{2}{*}{ Type of the job } & Permanent & 220 & $70.5 \%$ \\
\hline & Temporary & 92 & $29.5 \%$ \\
\hline \multirow{2}{*}{$\begin{array}{l}\text { Previous } \\
\text { working } \\
\text { experiences }\end{array}$} & Yes & 140 & $44.9 \%$ \\
\hline & No & 172 & $55.1 \%$ \\
\hline \multirow{5}{*}{$\begin{array}{l}\text { Working } \\
\text { duration of } \\
\text { the garment } \\
\text { factory }\end{array}$} & $\leq 1$ year & 81 & $26.0 \%$ \\
\hline & $2-7$ years & 193 & $61.9 \%$ \\
\hline & 8-13 years & 34 & $10.9 \%$ \\
\hline & $14-19$ years & 1 & $0.3 \%$ \\
\hline & $\geq 20$ years & 3 & $1.0 \%$ \\
\hline \multirow{4}{*}{$\begin{array}{l}\text { Duration of } \\
\text { work per day } \\
\text { (hours) }\end{array}$} & $\leq 5$ & 2 & $0.6 \%$ \\
\hline & $6-7$ & 7 & $2.2 \%$ \\
\hline & $8-9$ & 228 & $73.1 \%$ \\
\hline & $\geq 10$ & 75 & $24.0 \%$ \\
\hline \multirow{4}{*}{$\begin{array}{l}\text { Duration of } \\
\text { overtime per } \\
\text { week (hours) }\end{array}$} & $\leq 5$ & 123 & $39.4 \%$ \\
\hline & $6-10$ & 167 & $53.5 \%$ \\
\hline & $11-15$ & 3 & $1.0 \%$ \\
\hline & $\geq 16$ & 19 & $6.1 \%$ \\
\hline
\end{tabular}

Among the participants 174 (55.8\%) were sewing machine operators. Reason for this was the increased number of female workers in the sewing section. Majority of them have permanent jobs (70.5\%) and only 140 (44.9\%) participants had previous working experiences in garment industry. More than half of them (61.9\%) have been working in their factories for 2-7 years. And also $73.1 \%$ of participants worked 8-9 hours per day and $53.5 \%$ of them worked $6-10$ hours as over time per week.
Table 3. Prevalence of traumatic injuries and associated factors

\begin{tabular}{|c|c|c|c|}
\hline Characteristic & Categories & Frequency & Percentage \\
\hline \multirow{2}{*}{$\begin{array}{l}\text { Traumatic } \\
\text { injuries (during } \\
\text { last } 12 \text { month) } \\
\end{array}$} & Yes & 110 & $35.3 \%$ \\
\hline & No & 202 & $64.7 \%$ \\
\hline \multirow[t]{7}{*}{$\begin{array}{l}\text { Type of the } \\
\text { injury }\end{array}$} & $\begin{array}{l}\text { Puncture } \\
\text { injuries }\end{array}$ & 53 & $48.2 \%$ \\
\hline & $\begin{array}{l}\text { Laceration/ } \\
\text { Amputations }\end{array}$ & 1 & $0.9 \%$ \\
\hline & $\begin{array}{l}\text { Contusion/ } \\
\text { Abrasion }\end{array}$ & 21 & $19.1 \%$ \\
\hline & $\begin{array}{l}\text { Fracture/ } \\
\text { Dislocation }\end{array}$ & 3 & $2.7 \%$ \\
\hline & Cuts & 12 & $10.9 \%$ \\
\hline & Burns & 4 & $3.6 \%$ \\
\hline & Other & 16 & $14.0 \%$ \\
\hline \multirow{10}{*}{$\begin{array}{l}\text { Location of the } \\
\text { injury }\end{array}$} & Head & 9 & $8.2 \%$ \\
\hline & Neck & 4 & $3.6 \%$ \\
\hline & Trunk & 2 & $1.8 \%$ \\
\hline & Upper limb & 90 & $81.8 \%$ \\
\hline & $\begin{array}{l}\text { Arm and } \\
\text { elbow }\end{array}$ & 8 & $8.9 \%$ \\
\hline & $\begin{array}{l}\text { Forearm and } \\
\text { wrist }\end{array}$ & 5 & $5.6 \%$ \\
\hline & Hand & 25 & $27.8 \%$ \\
\hline & Fingers & 52 & $57.8 \%$ \\
\hline & Lower limb & 4 & $3.6 \%$ \\
\hline & $\begin{array}{l}\text { Multiple } \\
\text { locations }\end{array}$ & 1 & $0.9 \%$ \\
\hline \multirow{2}{*}{$\begin{array}{l}\text { Hospitalization } \\
\text { due to injury }\end{array}$} & Yes & 13 & $11.8 \%$ \\
\hline & No & 97 & $88.2 \%$ \\
\hline \multirow{2}{*}{$\begin{array}{l}\text { Sickness } \\
\text { absences due to } \\
\text { injury }\end{array}$} & Yes & 32 & $29.1 \%$ \\
\hline & No & 78 & $70.9 \%$ \\
\hline \multirow{7}{*}{$\begin{array}{l}\text { Worker related } \\
\text { cause of the } \\
\text { injury }\end{array}$} & Carelessness & 22 & $25.5 \%$ \\
\hline & Sleepiness & 2 & 1.85 \\
\hline & Rushing & 51 & $46.4 \%$ \\
\hline & Inexperience & 10 & $9.1 \%$ \\
\hline & $\begin{array}{l}\text { Not well } \\
\text { trained }\end{array}$ & 3 & $2.7 \%$ \\
\hline & $\begin{array}{l}\text { No using } \\
\text { or lack of } \\
\text { protective } \\
\text { measures }\end{array}$ & 5 & $4.5 \%$ \\
\hline & Other & 11 & $10.0 \%$ \\
\hline
\end{tabular}


Among the participants, 110 (35.3\%) were reported traumatic injuries during the previous 12 month period while 202 (64.7\%) participants have not reported traumatic injuries during the previous 12 months. So according to the study, $35.3 \%$ prevalence of traumatic injuries among female workers was found during the previous 12 month period.

Table 4. Nature of the working environment

\begin{tabular}{|l|c|c|c|}
\hline Characteristic & Categories & Frequency & Percentage \\
\hline Facilities for prevent accidents & Yes & 287 & $92.0 \%$ \\
\hline & No & 25 & $8.0 \%$ \\
\hline Fixed working hours & Yes & 263 & 84.35 \\
\hline & No & 49 & $15.7 \%$ \\
\hline Fixed breaks during working hours & Yes & 289 & $92.6 \%$ \\
\hline & No & 23 & $7.4 \%$ \\
\hline $\begin{array}{l}\text { Safety satisfaction regarding safety of the working } \\
\text { environment }\end{array}$ & Yes & 285 & $91.3 \%$ \\
\hline & No & 27 & $8.7 \%$ \\
\hline
\end{tabular}

\section{Discussion}

Work related injuries are concern as a major public health problem today. A study done in New Delhi, India found that major and minor accidents are common in the garment industry (8). The garment industry is the largest Sri Lankan gross export earner since 1986 and the major mode of foreign exchange earner since 1992 (1). It is provides over 300,000 to 600,000 employment opportunities for a majority of women (3). Awareness about the prevalence and associated factors of traumatic injuries among female workers is important for policy makers to take necessary actions for the improvement of occupational health among the female garment factory workers. So the main objective of this study was to assess the prevalence of traumatic injuries and identify their associated factors among female workers in garment Industry.

The study sample consists 312 female workers from two garment factories in Dickwella divisional secretariat area. The mean age rage was $26-35$ years. Majority of them (34.6\%) belonged to the age group 16-25 while nearly all of the participants were (99.68\%) Sinhala and Buddhists. 183 (58.7\%) of them were married and 158 $(83.2 \%)$ of them had children. Most of the participants had studied up to G.C.E. O/L (63.8\%). There were only 79 participants who had studied up to G.C.E. A/L or more. Among the participants 174 (55.8\%) were sewing machine operators. Reason for this was the increased number of female workers in the sewing section. Majority of them have permanent jobs (70.5\%) and only 140 (44.9\%) participants had previous working experiences in garment industry. More than half of them (61.9\%) have been working in their factories for 2-7 years. And also $73.1 \%$ of participants worked 8-9 hours per day and $53.5 \%$ of them worked $6-10$ hours as over time per week. According to the study, 35.3\% prevalence of traumatic injuries among female workers was found during the previous 12 month period. There were 110 female workers who were injured during the previous 12 month period from the 312 participants.

Sewing machine operators were the group with highest reported prevalence $(64.5 \%)$ of traumatic injuries (there were high numbers of sewing machine operators than others in both factories). According to the study most of these injuries were puncture injuries (48.2\%). Upper limb $(81.8 \%)$ was the commonest injured body part. This was due to high number of sewing machine operators within factories than other sections. Among the individuals who had traumatic injuries 56 (50.9\%) participants had no experiences in garment industry and 62 (56.4\%) of them have been working in garment factories for a duration of 2-7 years. $73(66.4 \%)$ of them worked 8-7 hours per day while 58 ( $52.7 \% 0$ participants worked $6-10$ hours per week as over time.

Rushing is the most common worker related cause for traumatic injuries. There were 51 (46.4\%) participants who mentioned rushing as their worker related cause of injury. Because of the workers busy daily working schedules this could happen. The workers always try to cover their daily target and because of that rushing is the most common cause for traumatic injuries among participants. Carelessness is another common cause (25.5\%) for traumatic injuries. Most of the participants thought they had adequate facilities for prevent 
accidents within their garment factories and nearly all of them (308 participants) had training of first aids, training of fire extinguishing or both. So no using or lack of protective measures were relatively uncommon (4.5\%) cause for traumatic injuries.

There were high prevalence of traumatic injuries among sewing machine operators (64.5\%). According to chisquare test there is a significant difference between the natures of the job with prevalence of traumatic injuries. Other than this there is only significant difference between the duration of work per day with prevalence of traumatic injuries. According to study most of traumatic injuries were minor injuries which did not need hospitalization or sick leave. Only $13(11.8 \%)$ participants were hospitalized due injuries and 32 (29.1\%) out of 110 participants were had been absent for work due to injuries.

The workers who were injured received first aid from the factory nurse. In rare cases, when it the injury was of a more serious nature, the nurse took the patients to the nearest hospital or to an appropriate medical centre close to the factory. 285 (91.3\%) participants were satisfied about their working environment safety. But the injury prevalence was high due other worker related cause such as rushing and carelessness.

There were only significant differences between the nature of the job with prevalence of traumatic injuries and duration of work per day with prevalence of traumatic injuries.

\section{Conclusion}

Findings of this study revealed there was a high traumatic injury prevalence among female workers in garment industry in Dickwella divisional secretariat area. Although they have good working environment in their factories, worker related causes such as rushing and carelessness was the reasons for these injuries. Puncture injuries are the commonest type of injuries and upper limb is the most affected body part.

Sewing machine operators are most commonly affected group. As there are high number of sewing machine operators than the workers in other sections.

There are only significant difference between the nature of the job with prevalence of traumatic injuries and duration of work per day with prevalence of traumatic injuries.

\section{References}

1. Deerasinghe, R., (2009) Garment industry in Sri Lanka Challenges, Prospects and Strategies. [Online]

2. Board of Investment of Sri Lanka. (2015) Key sectors for investment - Apparel. [Online]

3. Gurusinghe, G., (2012) Industry capability report Srilankan apparel sector. Export Development Board.

4. Hancock, P., Moore, J. \& Middleton, S., (2011) A quantitative study of women in Sri Lanka's Export Processing Zones: capital accumulation and social investment: Labour and Management in Development.

5. Lu, J, K., (2011) occupational health and safety of woman workers: viewed in the light of labour regulations: Journal of International Women's Studies.12 (1), 68-78.

6. University of Florida. (2015) Traumatic injury.

7. Lawson, K., (n.d.) what is the difference between major \& minor injuries in the workplace?

8. Calvin, S, \& Joseph, B., (2006) occupation related accidents in selected garment industries in Bangalore city: Indian Journal of Community Medicine. 31(1), 150-152.

9. Wikipedia. (2012) Occupational Injury

10. Dissanayake, C., \& Fonseka, R, T., (2014) Blood on the factory floor - industrial accidents soar: The Sunday Times 